\title{
A Case of Infectious Mononucleosis with Concurrent EBV and CMV IGM Seropositivity
}

\section{Christodoulos Monastiriotis* \\ Melathron agoniston EOKA, Cyprus}

*Corresponding author: Christodoulos Monastiriotis, Melathron agoniston EOKA, Limasol, Cyprus, Email: c_monastiriotis@yahoo.com

\section{Case Report \\ Volume 3 Issue 4}

Received Date: October 12, 2019

Published Date: October 21, 2019 DOI: $10.23880 /$ vij- 16000224

\section{Abstract}

Infectious mononucleosis is a common viral infection affecting mainly children, adolescents and young adults. Its main aetiology is Epstein - Barr Virus followed by Cytomegalovirus.

We present the case of a 26-year old lady, presented with clinical and laboratory features of the disease, with serologic evidence of concurrent EBV and CMV IgM positivity. Whether this represents a simultaneous infection or a previous infection by the one virus, boosted by the sequential infection by the second one, is very difficult to distinct.

\section{Case Report}

A 26 year old woman visited our clinic complaining for sore throat for three days, accompanied by high fever that reached $39^{\circ} \mathrm{C}$. She tried to control the situation receiving $1 \mathrm{~g}$ of paracetamol 3 times daily for the first 2 days and then she started amoxicillin 500mg twice daily. She decided to ask for medical help because her symptoms insisted in spite of all these. Her medical history was unremarkable, and no significant family history was reported. However she referred that she was taking care of her sister's 3 year old boy during next week when he was also sick and did not go to the nursery school.

On physical examination, fever was $38^{\circ} \mathrm{C}$, blood pressure $105 / 65 \mathrm{mmHg}$, pulse rate $110 / \mathrm{min}$, respiratory rate $16 / \mathrm{min} \mathrm{SaO}_{2}$ 96\%. Her pharynx was hyperemic, covered by a white colored exudate. There were several painful, swollen, cervical lymph nodes bilaterally. Lung and heart examination were normal. Spleen was palpated 3-4 cm below left costal margin.

In laboratory tests: white blood cells $7900 / \mu$ l with $59,6 \%$ lymphocytes and many of the characteristic, ballerina skirt -like atypical lymphocytes detected in the examination of the peripheral blood smear. SGOT $65 \mathrm{U} / \mathrm{L}$, SGPT $68 \mathrm{U} / \mathrm{L}$ and all other parameters within normal ranges. Viral antibodies were as follows: EBV IgM 2,09 $\mathrm{AU} / \mathrm{ml}$ (positive $>1,0$ ), EBV IgG 60,90 AU/ml (positive $>1,0$ ), CMV IgM 5,24 (positive >1,0), CMV IgG 4,11 (positive $>1,0$ ) and a negative Monospot test.

According to all these clinical and laboratory findings, the diagnosis of infectious mononucleosis was set, amoxicillin was discontinued, and conservative measures were suggested with intensive hydration and paracetamol dosages of $1 \mathrm{~g}$ when temperature exceeds $38^{\circ} \mathrm{C}$.

Two days later the patient returned to show us her swollen abdomen. There was a large splenomegaly reaching the periumbilical region. The spleen was rather stiff and painless. The patient was suggested to continue conservative therapy and avoid any physical activity for a month minimum until she was going to be seen again.

She visited us again, as scheduled, after a month of uncomplicated recovery, in a very good condition, her spleen having hardly being palpated and transaminases restored to normal values. 


\section{Discussion}

Infectious mononucleosis is a viral infectious syndrome characterized by pharyngitis, fever and lymphadenopathy [1]. Epstein-Barr virus is the main cause of the condition accounting for about $90 \%$ of cases [2]. More than half of the rest are due to Cytomegalovirus [3].

The laboratory hallmark of the disease is the lymphocytic preponderance defined as an absolute count of $4500 / \mathrm{mm}^{3}$ or a rate greater than $10 \%$. Atypical lymphocytes are present and may contribute up to $10 \%$ of the total. Up to $80 \%$ of patients present with notable transaminase elevations but jaundice are less common [4].

Monospot is a rapid test commonly used for the diagnosis of infectious mononucleosis. This detects heterophile antibodies with a sensitivity of $85 \%$ and specificity near $100 \%$ [5].

Although it is practically impossible to distinguish dual infection from sequential infections, in the lack of previous antibody titles, the latter is a probability. The vast majority of adults are considered to be seropositive for EBV, having been infected during early childhood via saliva $[6,7]$. Acute CMV infection can reactivate immunity against EBV. However the reverse does not appear to occur [8].

On the other hand, history of contact with a sick child is more consistent with an EBV transmission, as is the predominance of pharyngitis and lymphadenopathy that are not so loud in CMV infections $[9,10]$.

After all a recent study claims that, at least in children with primary EBV infection, dual seropositivity is a false positive finding due to antigenic cross- reactivity rather than a result of confection with CMV [11]. Whether our patient is such a case or not, is impossible to say, as there is no model to predict it, and additional studies are needed to confirm that theory.

\section{References}

1. Olson D, Huntington MK (2009) Co-Infection with cytomegalovirus and Epstein-Barr Virus in Mononucleosis: Case report and Review of Literature. South Dakota Journal of Medicine 62(9): 351-353.

\section{Virology \& Immunology Journal}

2. Aronson MD, Auwaerter PG (2019) Infectious Mononucleosis.

3. Kremola E, Von Essen R, Henle G, Henle W (1970) Infectious-mononucleosis-like disease with negative heterophil agglutination test. Clinical features in relation to Epstein-Barr virus and cytomegalovirus antibodies. J Infect Dis 121(6): 608-614.

4. Markin RS, Linder J, Zuerlein K, Mroczek E, Grierson $\mathrm{HL}$, et al. (1987) Hepatitis in fatal infectious mononucleosis. Gastroenterol 93(6): 1210-1217.

5. Linderholm M, Boman J, Juto P, Linde A (1994) Comparative evaluation of nine kits for rapid diagnosis of infectious mononucleosis and EpsteinBarr virus specific serology. J Clin Microbiol 32(1): 259-261.

6. Cohen JI (2000) Epstein- Barr virus Infection. N Engl J Med 343(7): 481-492.

7. Hadinoto V, Shapiro M, Sun CC, Thorley Lawson DA (2009) The dynamics of EBV shedding implicate a central role for epithelial cells in amplifying viral output. PLoS Pathog 5(7): e1000496.

8. Oill P, Fiala M, Schofferman J, Byfield P, Guze L (1977) Cytomegalovirus mononucleosis in a healthy adult: association with hepatitis, secondary Epstein -Barr virus antibody response and immunosuppression. Am J Med 62(3): 413-417.

9. Paloheimo JA, Halonen PI (1965) A case of mononucleosis-like syndrome after blood transfusion from a donor with asymptomatic mononucleosis. J Cardiovasc Surg (Torino) 6(6): 558-561.

10. Finkel M, Parker GW, Fanselau HA (1964) The hepatitis of infectious mononucleosis: experience with 235 cases. Mil Med 129: 533-538.

11. Sohn MJ, Cho JM, Moon JS, Ko JS, Yang HR (2018) EBV VCA IgM and cytomegalovirus IgM dual positivity is a false positive finding related to age and hepatic involvement of primary Epstein- Barr virus infection in children. Medicine 97(38): e12380.

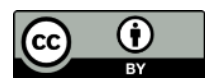

Christodoulos Monastiriotis. A Case of Infectious Mononucleosis with Concurrent EBV and CMV IGM Seropositivity. Virol Immunol J 2019, 3(4): 000224. 